\title{
The historical consciousness of student youth and evaluation of the events of the Great Patriotic War
}

\author{
Sergei P. Kostrikov ${ }^{1 *}$, Andrey A. Kolchin ${ }^{1}$, Yuliya P. Nadekhina ${ }^{1}$, Elena V. Kryukova ${ }^{1}$, and \\ Stanislav S. Kostrikov ${ }^{2}$ \\ ${ }^{1}$ State University of Management, Department of History and Political Science, Moscow, Russia \\ ${ }^{2}$ State University of Management, Department of State and Municipal Administration, Moscow, \\ Russia
}

\begin{abstract}
It is not the first year that the information space has been marked by trends in the revision of evaluations of the events of the Great Patriotic War. Student youth are actively and rapidly developing, adapting to the new social realities. That is why the issues of preserving historical memory and developing the historical consciousness of contemporary young people have become so relevant. The present work is based on the analysis of the survey results of the 1st and 2nd-year students conducted at the State University of Management (SUM, Moscow, Russia), and is a continuation of the research devoted to the evaluation of the end results of the Great Patriotic War in the perception of University students. An attempt was made to determine the level of students' knowledge about the main facts of the Great Patriotic War. Within the framework of this study, the results of similar works by domestic and foreign authors were considered. As a rule, in Russia, the problem of awareness of the importance of the Great Patriotic War is emphasized in terms of its results, including the perception of these issues by student youth. At the same time, several foreign authors put forward the issue of reevaluating the results of the Second World War and make it with clear politicization of the proposed conclusions, primarily, in determining the historical responsibility for war unleashing. The authors of the present study propose to strengthen the role of archival documents, memoirs, chronicles, and testimonies of direct participants and victims of the wartime events in military-historical education, which should not allow distorting the historical feat of the USSR and its decisive contribution to the defeat of Nazi Germany.
\end{abstract}

Keywords: historical memory, historical consciousness, the Great Patriotic War, student youth.

\section{Introduction}

The issues of historical memory and historical consciousness are important in the formation of active civic-minded young people. Currently, these issues are becoming even more

\footnotetext{
${ }^{*}$ Corresponding author: sp_kostrikov@guu.ru
} 
relevant. By the beginning of the 90s, the events of the Great Patriotic War were largely interpreted in the same way in Russia and abroad. However, in recent years, several Western countries have been reviewing the place and role of various states in the Second World War (WWII). Current information technologies allow spreading these opinions to the widest possible audience, and, first of all, the young people, who, unlike their parents, know little about the events 75 years ago.

\section{Methods}

The hypothesis of the present study is the statement of the quantitative growth of people with a distorted or fragmentary view of historical events related to the Great Patriotic War, which was not least caused by increased attempts to falsify the historical past.

A special place is occupied by the issue of historical responsibility for the outbreak of the WWII, of which the Great Patriotic War was an integral part. Foreign studies of modernity promote the theory that the cooperation of England and the USA played a key role in the defeat of Nazi Germany [1]. Increasingly, the WWII becomes not a historical, but a political reference point for understanding the international system of the 21 st century, which leads to distortions of the past [2].

The above has formed the ideological platform that defined the questions of the new updated survey.

\section{Results}

A previous study conducted in September 2020 has shown that to form mature civic-minded students, free from ideological clichés and political conjuncture, as well as for their subsequent activities in professional communities, it is necessary to resist attempts to distort and falsify history, including that in the information space [3]. The study has identified a problem associated with a decrease in the level of knowledge of young people about specific historical facts, including the Great Patriotic War.

First- and second-year students of the State University of Management were involved in the survey. A total of 202 people were interviewed. The questionnaire consisted of three questions.

The first question requested respondents to indicate the full dates of the start and the end of the Great Patriotic War. The results were ambiguous. Thus, $73.8 \%$ of students were able to give answers; $9.9 \%$ of respondents indicated correctly only the start and end years of the Great Patriotic War; $3.5 \%$ of students indicated correctly only the start date; $1.5 \%$ of students - only the end date, while $11.3 \%$ of respondents gave an incorrect answer.

Among the most common mistakes, the end date of the Great Patriotic War was indicated as 7.05.1945. The next common mistake was specifying the start and the end dates of the WWII instead of the requested dates. Finally, some dates had nothing to do with the question. Here one should note that O.A. Verevkina in her research, devoted to the peculiarities of the historical memory of young people about the events of the Great Patriotic War, also indicated a low level of knowledge of historical dates [4].

The second question was: "Whom of the heroes of the Great Patriotic War do you know?" Four rows of historical figures with four surnames each, selected from different periods of Russian history, were offered as answers. Not the most obvious characters were listed. This was done to assess the depth of the students' personalized knowledge [5]. Thus, the first row in the list indicated the Decembrists, the second row - the heroes of the Patriotic War of 1812, while the third row included names of the Great Patriotic War marshals, and the last row listed names of commanders of the First World War. 
Results were as follows: $45.5 \%$ of the surveyed students chose the correct names, $10.9 \%$ of students did not answer the question. At that, $11.9 \%$ of students emphasized different surnames from different rows. Some students indicated several options at once: $3 \%$ of students chose the first two rows; $3.5 \%$ of students noted the second and the third rows. $13.3 \%$ of respondents chose the Decembrists, while $11.9 \%$ of students named the heroes of the Patriotic War of 1812.

It is obvious that the historical memory of today's students makes such mistakes, and this is confirmed by other studies. For example, in January-February 2020, the Far Eastern Federal University conducted a study on the analysis of ideas about war through literary works and art. As the survey data showed, some of the interviewed young people attributed the monument to Minin and Pozharsky, the cruiser Aurora, etc. to the monuments of the Great Patriotic War [3].

The third question of the questionnaire was: "Which of the countries does, in your opinion, bear the main historical responsibility for the outbreak of the WWII, whose integral part is the Great Patriotic War of the Soviet people?" The question suggested students select one or more countries from the list or specify their own version in the "other" section. According to answers, $75.7 \%$ of respondents chose Germany, while $9.4 \%$ of students chose the USSR. Noteworthy is the comment of one of the respondents, who justified his choice as follows: "The USSR. (The Molotov-Ribbentrop Pact was the trigger for the outbreak of the Second World War, at the beginning of which the USSR waged a war of conquest together with the Third Reich, against Poland). Such maxims are not uncommon today. They are distributed through the media, which replicate political statements about the WWII outside the historical paradigm. Moreover, $4 \%$ of students surveyed chose the USA, while $2 \%$ of students chose the UK. At that, $8.9 \%$ of respondents preferred the item "other", in which they either indicated various combinations of the countries proposed in the response or indicated their version.

\section{Discussion}

The conclusions made by the authors coincide with the research of many specialists. Thus, N.V. Vorobyova, in the course of her research on citizenship and patriotism of student youth, concluded that from year to year, a pronounced trend leading to a decrease in citizenship and patriotism was revealed, despite the increase in academic performance. This is influenced by the reduction of classroom hours for teaching history and the reduction of disciplines of the general humanitarian cycle [6]. Based on a sociological study, G.S. Shirokalova believes that the recently formed patriotic self-identification of Russians contains more of a verbal expression of loyalty to the generally accepted opinion [7]. I.A. Batanina notes that currently the demand for politically patriotic perception of the results of the Great Patriotic War prevails in society [8]. According to V.V. Kovrov, the formation of ideas about heroes and the heroic in the minds of young people is influenced by the falsification and deheroization technologies used in various mass media [9].

In the study conducted by S.D. Lebedev and I.S. Shapovalova within the framework of regional monitoring of the Russian Society of Sociologists, entitled "What do we know about the Great Patriotic War" (2005-2020), it is noted that "the liberation of the Baltic states, Eastern Europe during 1944-1945 was occupation". At that, 21\% of the interviewed considered this statement to be debatable but discussible, while $45.4 \%$ of respondents were undecided with an answer. At the same time, $6.7 \%$ of interviewed were students who agreed with such statement [10].

However, A.L. Andreev in his research claims that the student youth of Belarus perceive with sympathy and respect the years of spiritual uplift associated with the Victory in the Great Patriotic War and the liberation of European countries from fascism [11]. Today, most Poles 
continue to believe that the memory of prejudice and discrimination associated with Germany during the WWII still has great influence on the attitude of Poles towards Germans [12]. Many in contemporary Europe are convinced that the WWII was certainly a global event, but its history was considered and studied from national standpoints for a long time, which does not allow today reaching a compromise in evaluations of this historical event [13-15].

\section{Conclusion}

In summary of the conducted study, the following conclusions can be drawn:

1. The ideas of student youth about the main facts of the Great Patriotic War and its results, in general, are historically substantiated, which is supported by both the power of state propaganda and subject courses delivered at educational institutions;

2. Some young people lack basic ideas about the facts and evaluations concerning the Great Patriotic War, and their number is growing;

3. Since with further moving away from the events of the WWII and the Great Patriotic War, the attempts to revaluate this historical event will increase, it is necessary to strengthen seriously the role of archival documents, memoirs, testimonies of participants and victims of the wartime events in the military history education, which should not allow belittling the historical feat of the multinational Soviet people and their decisive contribution to the defeat of Nazi Germany.

Both questionnaires were addressed to the students for whom the study of history in the framework of their educational areas was not a profile subject. In the future, it is advisable to address cadets of military universities, as well as students majoring in history, as respondents for such surveys. This will expand the sociological base of the research and allow covering the part of the student youth who are motivated towards historical science.

\section{References}

1. Th.W. Bottelier, European Review of History: Revue européenne d'histoire, 27(1-2), 152-175 (2020). https://doi.org/10.1080/13507486.2019.1705251

2. M. Shaw, Critical Studies on Security, 3(3), 285-289 (2015). https://doi.org/10.1080/21624887.2015.1123952

3. A.A. Kolchin, Yu.P. Nadekhina, The results of the Great Patriotic War in the perception of student youth, in Proceedings of the Annual International Forum Obshchestvo. Doveriye. Riski [Society. The trust. Risks], 467-473 (Ministerstvo Nauki i Vysshego Obrazovaniya Rossiyskoy Federatsii, Gosudarstvennyy Universitet Upravleniya, Moscow, 2020)

4. O.A. Verevkina, M.A. Kolpovskaya, Molodoy uchenyy, 19.1(99.1), 87-90 (2015)

5. P. Dukes, "Great men" in the Second World War: the rise and fall of the big three (Bloomsbury, London, 2017)

6. N.V. Vorobyova, Innovatsionnoye Obrazovaniye i Ekonomika, 21, 61-70 (2016)

7. G. S. Shirokalova, Historical and Social-educational Ideas, 10(3/2), 161-174 (2018). https://doi.org/10.17748/2075-9908-2018-10-3/2-161-174

8. I.A. Batanina, A.V. Ponedelkov, T.V. Ignatova, S.A. Vorontsov, Izvestiya Tula State University. Humanitarian Sciences, 2, 3-11 (2020)

9. V.V. Kovrov, Gumanitarium, 1(2), 29-34 (2017) 
10. S.D. Lebedev, I.S. Shapovalova, N.A. Roshchupkina, A.A. Shkapenko, Research Result. Sociology and Management, 6(2), 3-18 (2020). https://doi.org/10.18413/24089338-2020-6-2-0-1

11. A.L. Andreev, I.V. Lashuk, Sociologicheskaja Nauka i Social'naja Praktika, 7(2), 34 45 (2019). https://doi.org/10.19181/snsp.2019.7.2.6408

12. D. Pipitone, Journal of Modern Italian Studies, 21(4), 627-648 (2016). https://doi.org/10.1080/1354571X.2016.1207322

13. E. Nasalska, Intercultural Education, 11(1), 53-64 (2000). https://doi.org/10.1080/14675980050005398

14. M. Siddi, European Politics and Society, 18(4), 465-479 (2017). https://doi.org/10.1080/23745118.2016.1261435

15. T.A. Krupa, Kontentus, 5, 9-19 (2020) 